\title{
Evaluation of Anxiolytic and Sedative-Like Activities of Methanolic Extract of Euphorbia hirta Leaves in Mice
}

\section{S. M. Mushiur Rahman1*, Sohel Rana1, Md. Nahinul Islam¹, Alok Kumer², Md. Mehedi Hassan, Tonmoy Kumar Biswas ${ }^{2}$, Md. Atikullah ${ }^{1}$}

${ }^{1}$ Department of Pharmacy, Jashore University of Science and Technology, Jashore, Bangladesh

${ }^{2}$ Department of Pharmacy, State University of Bangladesh, Dhaka, Bangladesh

${ }^{3}$ Department of Pharmacy, University of Asia Pacific, Dhaka, Bangladesh

Email: *smushiurjustphar@gmail.com

How to cite this paper: Rahman, S.M.M., Rana, S., Islam, Md.N., Kumer, A., Hassan, Md.M., Biswas, T.K. and Atikullah, Md. (2019) Evaluation of Anxiolytic and Sedative-Like Activities of Methanolic Extract of Euphorbia hirta Leaves in Mice. Pharmacology \& Pharmacy, 10, 283-297. https://doi.org/10.4236/pp.2019.106023

Received: May 13, 2019

Accepted: June 14, 2019

Published: June 17, 2019

Copyright $\odot 2019$ by author(s) and Scientific Research Publishing Inc. This work is licensed under the Creative Commons Attribution International License (CC BY 4.0).

http://creativecommons.org/licenses/by/4.0/

\begin{abstract}
In indigenous or folk medicine, Euphorbia hirta is a very popular herb and used as a palliative to treat various ailments including intestinal parasites, diarrhoea, vomiting, amoebic dysentery, asthma, bronchitis, emphysema, coughs, kidney stones, menstrual problems etc. The objective of this study is to evaluate the anxiolytic and sedative-like effects of the methanol extract from the leaves of Euphorbia hirta (Euphorbiaceae). Methanolic extract of Euphorbia hirta was evaluated for its CNS depression effect using mice behavioral models such as, elevated plus maze and hole board test for its anxiolytic potential where hole cross and pentobarbital-induced sleeping time tests were performed for its sedative properties, respectively. The test group received three different doses of the MEHL (100 mg/kg, $200 \mathrm{mg} / \mathrm{kg}$ and $300 \mathrm{mg} / \mathrm{kg}$ ) orally. The positive control group received diazepam $(1 \mathrm{mg} / \mathrm{kg})$ orally where the negative control group received distilled water $(10 \mathrm{ml} / \mathrm{kg})$ orally. In elevated plus maze test, the extract exhibited significant $(\mathrm{p}<0.05)$ increased the number of open arm entry and time spent in open arm by mice compared to control group. In addition, the number of head dips and hole crosses significantly $(\mathrm{p}<0.05)$ decreased by mice in hole board and hole cross tests respectively, compared to control group. Moreover, mice treated with MEHL significantly decrease the onset of sleep and increase the duration of sleep in pentobarbital-induced sleeping time test in mice compared to control group. The data obtained from the present study clearly demonstrate that the methanolic extract of Euphorbia hirta has potential anxiolytic and sedative-like activity in the animal behavioral models. And the findings represent a rational explanation for its use in traditional medicine for the management of neurological disorder.
\end{abstract}




\section{Keywords}

Euphorbia hirta, Anxiolytic, Sedative, Elevated Plus Maze, Hole Board, Hole Cross

\section{Introduction}

From the primitive period of time, plant derived medicines have been used for the well-being of mankind as palliative to cure the series of human ailments. Everyday, thousands of researchers are inquiring for new drugs with safe and effective therapeutic actions. It is crucial to find plant derived new drugs because they are more effective, cheap and have little side effects. But there is a problem associated with the therapeutic uses of plant derived products that it has the lack of scientific evidence supporting the claimed uses. About $80 \%$ of the world population are still depends predominantly on plant based crude drugs according to WHO. Nature provides an excellent source of bioactive compounds that are derived from medicinal plants and it serves as raw materials for discovering noble and new drugs with considerable less adverse or side effects [1] [2].

Euphorbia hirta L. belongs to the plant family Euphorbiaceae (locally known as dudhani, dudhi) and considered as the largest genus of this family. It is usually erect, slender-stemmed, annual hairy plant with many branches from the base to top, spreading upto $40 \mathrm{~cm}$ in height, though sometimes it can be seen lying down, reddish or purplish in color. The plant is a small annual broad-leaved herb common to tropical countries. Leaves are opposite, elliptical, oblong or oblong-lanceolate, acute or subacute, dark green above, pale beneath, $1-2.5 \mathrm{~cm}$ long, with a faintly toothed edge and blotched with darker or purple on the middle or upper surface [3] [4]. The flowers are small, about $1 \mathrm{~cm}$ in diameter, numerous and crowded together in dense cymes. The leaves and stem produces a milky-white juice when cut. It is frequently seen growing open waste spaces, banks of watercourses, grasslands, road sides, and pathways [5].

E. hirta mainly contains flavonoids (quercetin, quercitrin, quercitol, rutin, leucocyanidin, leucocyanidol, myricitrin, cyanidin 3,5-diglucoside, pelargonium 3,5-diglucoside), terpenoids ( $\alpha$-amyrin, $\beta$-amyrin, friedelin, taraxerol, $\beta$-sitosterol, campesterol, cholesterol, and stigmasterol), phenols, essential oil, ellagic, gallic, tannic, maleic and tartaric acid and other compounds [6].

It is a very popular and trustworthy herb amongst practitioners of traditional medicine and widely used as a palliative to treat various ailments including intestinal parasites, diarrhoea, peptic ulcers, vomiting, amoebic dysentery, asthma, emphysema, bronchitis, coughs, hay fever, laryngeal spasms, colds, kidney stones, menstrual problems, sterility and venereal diseases. The plant has a reputation as an analgesic to treat severe headache, toothache, rheumatism, colic and pains during pregnancy. To pain relief of scorpion stings and snakebites it is 
used as an antidote [7]. Moreover, the sedative, anxiolytic, analgesic, antipyretic and anti-inflammatory, antifertility, anthelmintic, antiplasmodial, antiamoebic, antimalarial, larvicidal properties of E. hirta have been reported in the literature [3] [8].

In accordance with World Health Organization (WHO), depression is one of the top five most prevalent diseases worldwide and is becoming a rising concern in the current world as almost 450 million people around the world suffering from depression. By 2020, it is expected to be the second-leading cause of disability where $21 \%$ of the world population suffers from this disease. It is typically presented as lowered mood, difficulty in thinking, loss of interest and physical complaints such as headache, disturbed sleep, loss of energy and change in sex drive. Nowadays, it is also reported that anxiety along with depression is the most prevalent and high occurrence mental disorders at global level; together they are responsible for $50 \%$ of psychiatric and substance use disorders [9] [10] [11]. Approximately $32 \%$ of the populations of the USA are estimated to suffer from a CNS disorder [12].

Sedative and hypnotics are the drugs which are extensively used in treatment of anxiety, insomnia and depression. But continuous uses of these currently available sedative-hypnotic therapies produce a life threatening condition. Barbiturates and benzodiazepine are the commonly used in CNS depressant by interaction with postsynaptic gamma aminobutyric acid receptor (GABAA receptor). The most serious drawback of these drugs is psychological and physiological dependence and tolerance as well as immune system dysfunctions to deterioration of cognitive function [13] [14].

Thus, development of new sedative-hypnotic drugs with fewer side effects along with less expensive has been suggested to be a promising approach to combat different psychiatric disorders. So, the present study is designed to investigate the anxiolytic and sedative-like effect of MEHL in different behavioral model of depression in mice.

\section{Materials and Methods}

\subsection{Plant Collection and Identification}

With the help of a comprehensive literature review, Euphorbia hirta (Euphorbiaceae) was selected for this neuropharmacological investigation. Freshness leaves of this plant were collected from Jashore University of Science \& Technology Campus (located at $23^{\circ} 14^{\prime} 0^{\prime \prime} \mathrm{N}, 89^{\circ} 7^{\prime} 31^{\prime \prime} \mathrm{E}$ ), Jashore, Bangladesh, in September 2018. The plant was botanically identified and confirmed by National Herbarium, Bangladesh and the accession number is DACB-46543. A dried specimen was archived in the herbarium for future reference.

\subsection{Extract Preparation}

For methanol extraction, $300 \mathrm{gm}$. of powdered leaves were taken. First, the leaves of Euphorbia hirta were thoroughly washed 3 - 4 times successively with 
fresh current water and once with sterile distilled water to remove all dirt, soil, and contaminants and dried in shade at room temperature $\left(25^{\circ} \mathrm{C} \pm 2^{\circ} \mathrm{C}\right)$ for two weeks and finally dried them for 24 hours at $30^{\circ} \mathrm{C} \pm 2^{\circ} \mathrm{C}$ by using a laboratory dryer (memmert UN75, Germany) before to ground. The dried leaves were ground into coarse powder and cold extraction method was used to extract the active components. Around $300 \mathrm{gm}$. ground leaves were soaked in sufficient amount of analytical graded methanol $(1800 \mathrm{~mL})$ for 10 days at room temperature with periodical shaking and stirring. The whole mixture was primarily filtered through fresh cotton and then through Whatman No.1 filters. The solvent was evaporated at $40^{\circ} \mathrm{C}$ temperature to yield semisolid crude extract. The percentage yield of the extract was $4.19 \%(\mathrm{w} / \mathrm{w})$. The crude semisolid extract was then preserved in a refrigerator till further use.

\subsection{Experimental Animals}

To run this neuropharmacological evaluation, 4 - 5 weeks aged eighty male $S$ wiss albino mice of body weight $20-25 \mathrm{gm}$. were procured from Department of Pharmacy, Jahangirnagar University, Savar, Dhaka, Bangladesh. Before initiating these experiments, the animals were kept under standard environmental conditions, maintained $55 \%$ - $65 \%$ relative humidity and exposed to alternative 12:12 hours light and dark cycle at an ambient temperature of $26^{\circ} \mathrm{C} \pm 2^{\circ} \mathrm{C}$. They were housed in cages made of polypropylene with proper supplies of foods and water ad libitum was ensured. All protocols for animal experiment were approved by the Institutional Animal Ethical Committee of Jashore University of Science and Technology, Jashore, Bangladesh. Prior to experiment, mice were habituated for 10 days in our laboratory environment and ensured the constant environmental and adequate nutritional conditions throughout the period of the experiment.

\subsection{Chemical Reagents and Drugs}

Diazepam and Pentobarbitone were purchased from Square Pharmaceuticals Ltd., and Incepta Pharmaceuticals Ltd., Bangladesh, respectively. All other chemicals and reagents were obtained from Merck, Germany of analytical grade and high purity.

\subsection{Experimental Methods}

\subsubsection{Elevated Plus-Maze Test}

The elevated plus maze test was carried out according to the method of Lister [15] and with slight modification. This apparatus comprised two open arms (16 $\mathrm{cm} \times 5 \mathrm{~cm})$ and two closed arms $(16 \mathrm{~cm} \times 5 \mathrm{~cm} \times 10 \mathrm{~cm})$ that extended from a common central platform $(5 \mathrm{~cm} \times 5 \mathrm{~cm})$. The entire maze was $50 \mathrm{~cm}$ elevated from the floor used to observe anxiolytic behavior in animals. Experimental animals are divided into five groups with five mice in each group. The negative control group received distilled water, the positive control group (standard) received diazepam $(3 \mathrm{mg} / \mathrm{kg})$, and the three test groups received three different doses $(100,200$ and $300 \mathrm{mg} / \mathrm{kg}$ ) of Euphorbia hirta leaves extract. The mice were 
individually placed in the center of the elevated plus-maze with its head facing the open arms after one hour of respected treatment. Mice were observed for 5 minutes to record their behavioral effects. Different kind of parameter such as the number of entries by each mouse into open or closed arms and the time spent by each mouse in either open or closed arms were recorded with stopwatches.

\subsubsection{Hole-Board Test}

The hole-board test was used to determine potential anxiolytic effects according to the method described by Ozturk et al. [16] with slight modification. The hole-board apparatus composed of a gray wooden box $(40 \mathrm{~cm} \times 40 \mathrm{~cm} \times 25 \mathrm{~cm})$ with 16 equidistant holes (diameter $3 \mathrm{~cm}$ ) evenly spaced on the floor [17]. The center of each hole was $10 \mathrm{~cm}$ from the nearest wall of the box. The floor of the box was positioned $15 \mathrm{~cm}$ above the ground and divided into squares of $(10 \mathrm{~cm}$ $\times 10 \mathrm{~cm}$ ) with a water-resistant marker. Grouping and treating of experimental animals were done as described previously. After half hour of oral administration, each experimental animal was placed at the center of the board and allowed to explore the apparatus for $5 \mathrm{~min}$. The total number of head dips into the holes was recorded over a $5 \mathrm{~min}$ period. If both eyes disappeared into the hole then the head dip scored.

\subsubsection{Hole Cross Test}

Hole cross test was carried out according to the method of Komada et al. [18] and with slight modification. The apparatus made by wooden box $(30 \times 20 \times 14$ $\mathrm{cm}^{3}$ ) with a partition fixed in the middle of the box. A round hole of $3 \mathrm{~cm}$ diameter made from a height of $7.5 \mathrm{~cm}$ in the center of the box. Twenty five mice were divided randomly into five groups, where each group contained five mice. The negative control group received distilled water $(10 \mathrm{~mL} / \mathrm{kg}$, orally), the positive control group (standard) received diazepam $(1 \mathrm{mg} / \mathrm{kg})$, and the three test groups received three different doses (100, 200 and $300 \mathrm{mg} / \mathrm{kg}$ ) of Euphorbia hirta leaves extract respectively. Then the treated mice were placed in the center of one side of the apparatus. The number of passages of a mouse through the hole from one chamber to another chamber counted over a period of $3 \mathrm{~min}$ at 0 , $30,60,90$ and 120 min after the administration.

\subsubsection{Pentobarbital-Induced Sleeping Time}

To conduct the pentobarbital-induced sleeping test, the method of Williamson et al. [19] with slight modification was applied. Mice were randomly categorized into five groups consisting of five mice in each group. Grouping and treating of experimental animals were done as described previously. After 30 minute of treatment, pentobarbital ( $40 \mathrm{mg} / \mathrm{kg}$, i.p.) was administered to each mouse of all groups to induce sleep. The total sleeping time was recorded for both controls (positive and negative) as well as for test groups. Hence, animals were observed for the latent period (time between pentobarbitone administration to loss of righting reflex) and duration of sleep (time between the loss and recovery of 
righting reflex).

\subsection{Statistical Analysis}

All the results are expressed as mean \pm SEM (standard error of mean). For the analysis of all test results, one-way ANOVA following Dunnett's test $(p<0.05$, vs. control) was utilized. SPSS software (version 20; IBM Corporation, New York, USA) was used for the analysis of all data. The obtained results are compared with the vehicle control group. The significance is presented at the level of $p<0.05$. All graphs are generated by using Graph Pad Prism software.

\section{Results}

\subsection{Elevated Plus-Maze Test}

Table 1 displays the results of elevated plus maze test in mice. Mice treated with diazepam $(1 \mathrm{mg} / \mathrm{kg})$ or MEHL $(100 \mathrm{mg} / \mathrm{kg}, 200 \mathrm{mg} / \mathrm{kg}$ and $300 \mathrm{mg} / \mathrm{kg}$ respectively), significantly ( $p<0.05$, versus control) increase the frequency of the open arms entries and time spent in open arms when compared to the control. It was noticed that the frequency of the open arms entries and time spent in open arms of mice was increased, when it was treated with MEHL $300 \mathrm{mg} / \mathrm{kg}$ rather than MEHL $100 \mathrm{mg} / \mathrm{kg} \& 200 \mathrm{mg} / \mathrm{kg}$ respectively. In this test, MEHL produced anxiolytic effect in a dose dependent manner but the effect was lower than the standard drug diazepam. Results are illustrated in Figure 1.

\subsection{Hole-Board Test}

The results obtained from hole-board test are represents in Table 2. Mice of all groups, treated with MEHL (after $30 \mathrm{~min}$ of oral administration) at $100 \mathrm{mg} / \mathrm{kg}$, $200 \mathrm{mg} / \mathrm{kg}$ and $300 \mathrm{mg} / \mathrm{kg}$ respectively and diazepam $(1 \mathrm{mg} / \mathrm{kg})$ significantly decreased the head dips $(p<0.05)$ while compared with the control group. Anxiolytic effect of standard drug (diazepam, $1 \mathrm{mg} / \mathrm{kg}$ ) was higher than every dose of the extract. MEHL at a dose of $300 \mathrm{mg} / \mathrm{kg}$ showed the highest anxiolytic activity when compare with MEHL at a dose of $100 \mathrm{mg} / \mathrm{kg}$ and $200 \mathrm{mg} / \mathrm{kg}$. No significant effects observed at a dose of $100 \mathrm{mg} / \mathrm{kg}$. Here, MEHL exerted a dose-related decrease in head dips. Results are illustrated in Figure 2.

Table 1. Effect of MEHL on elevated plus maze test.

\begin{tabular}{cccccc}
\hline Group & Dose & open arm time & close arm time & open arm entry & close arm entry \\
\hline Control & $10 \mathrm{~mL} / \mathrm{kg}$ & $116.20 \pm 2.96$ & $183.80 \pm 2.96$ & $9.60 \pm 1.25$ & $16.60 \pm 1.60$ \\
Diazepam & $1 \mathrm{mg} / \mathrm{kg}$ & $211.40 \pm 7.71^{*}$ & $88.60 \pm 7.71^{*}$ & $16.40 \pm 1.66^{*}$ & $3.00 \pm 0.71^{\star}$ \\
MEHL & $100 \mathrm{mg} / \mathrm{kg}$ & $141.80 \pm 4.88^{*}$ & $160.20 \pm 5.26$ & $9.80 \pm 1.16^{*}$ & $14.40 \pm 1.36$ \\
MEHL & $200 \mathrm{mg} / \mathrm{kg}$ & $166.00 \pm 3.30^{*}$ & $134.00 \pm 3.30$ & $13.20 \pm 1.07^{*}$ & $9.40 \pm 1.36^{*}$ \\
MEHL & $300 \mathrm{mg} / \mathrm{kg}$ & $195.20 \pm 6.04^{*}$ & $104.40 \pm 6.02^{*}$ & $15.00 \pm 1.64^{*}$ & $7.60 \pm 0.93^{*}$
\end{tabular}

All of the experimental values are presented as mean \pm SEM $(n=5), M E H L=$ Methanol extract of Euphorbia hirta leaves. ${ }^{*} p<0.05$ vs. control group (Dunnett's test). 


\section{Elevated plus maze test:}

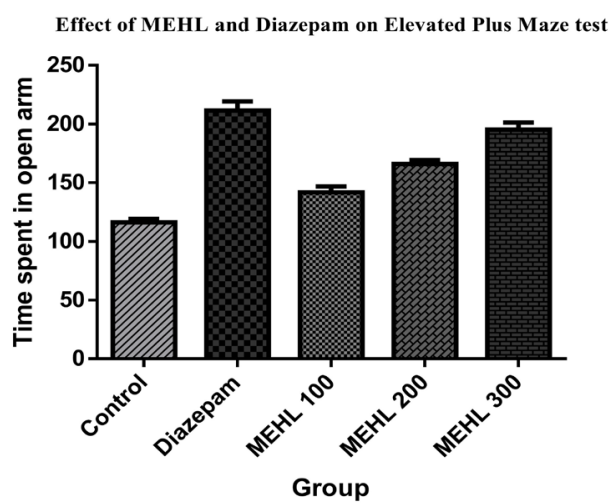

Effect of MEHL and Diazepam on Elevated Plus Maze test
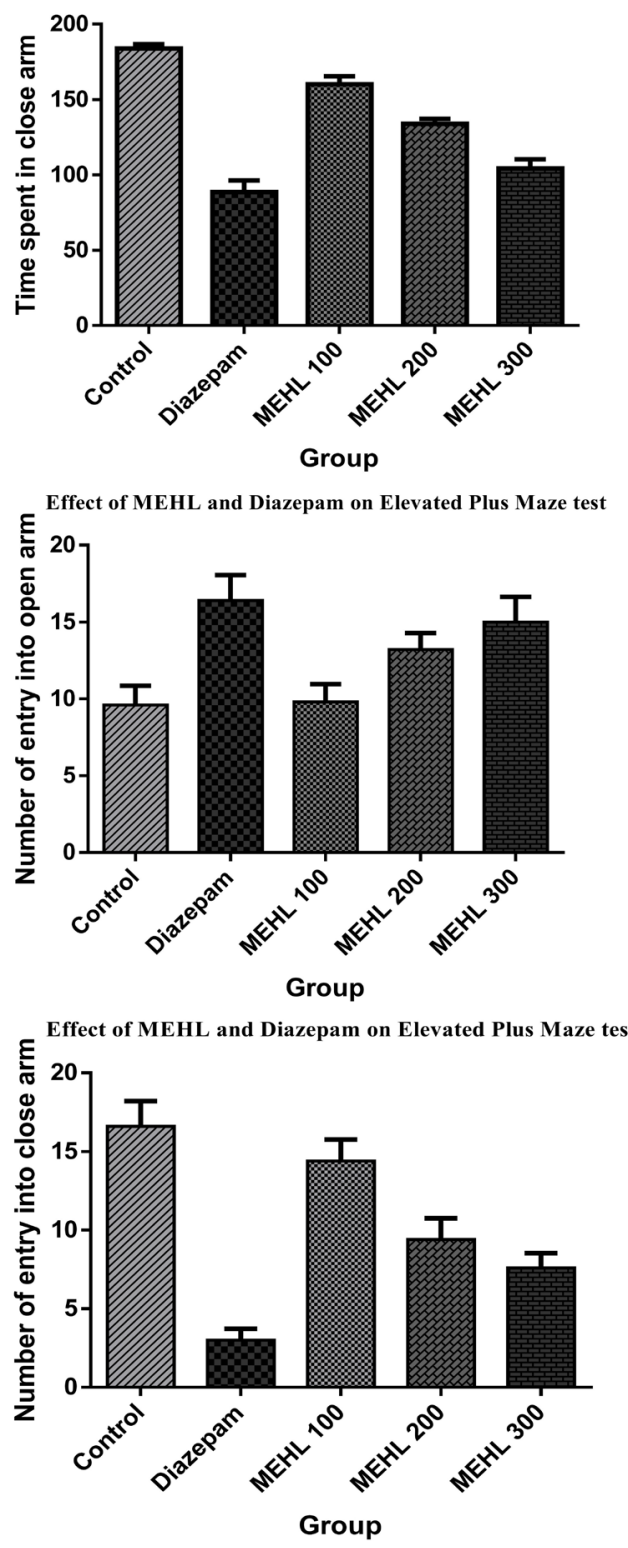

Figure 1. The effect of MEHL on elevated plus-maze test (Time spent in open arms; Time spent in close arms; Number of entries in open arms; Number of entries in close arms) in mice. ${ }^{\star} p<0.05$ vs. control (one way ANOVA followed by Dunnett's test). 
Table 2. Effect of MEHL on hole board test.

\begin{tabular}{ccc}
\hline Group & Dose & Number of head dips \\
\hline Control & $10 \mathrm{~mL} / \mathrm{kg}$ & $43.80 \pm 2.90$ \\
Diazepam & $1 \mathrm{mg} / \mathrm{kg}$ & $14.20 \pm 1.24^{*}$ \\
MEHL & $100 \mathrm{mg} / \mathrm{kg}$ & $38.00 \pm 2.21$ \\
MEHL & $200 \mathrm{mg} / \mathrm{kg}$ & $27.60 \pm 2.60^{*}$ \\
MEHL & $300 \mathrm{mg} / \mathrm{kg}$ & $17.40 \pm 1.66^{*}$ \\
\hline
\end{tabular}

All of the experimental values are presented as mean \pm SEM $(n=5)$, MEHL $=$ Methanol extract of Euphorbia hirta leaves. ${ }^{*} p<0.05$ vs. control group (Dunnett's test).

\section{Hole board test:}

Effect of MEHL and Diazepam on Hole board test

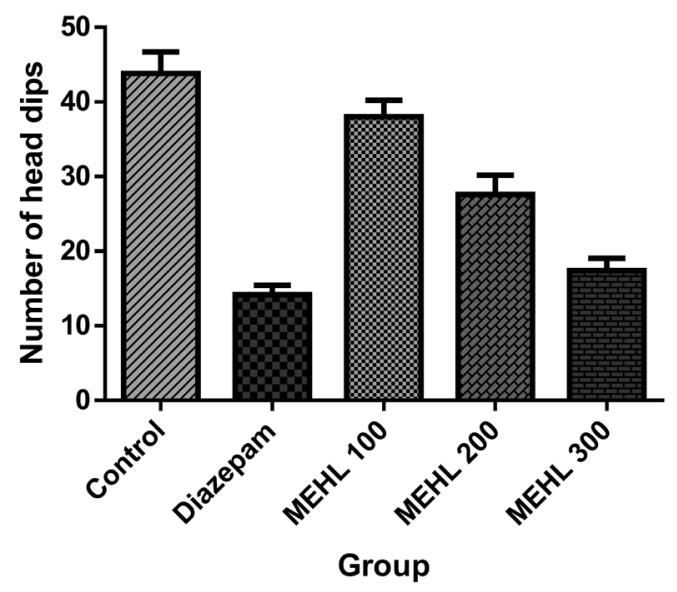

Figure 2. The effect of MEHL on hole board test (number of head dips) in mice. Each bar represents the mean \pm standard error of the mean of head dips of five animals. ${ }^{\star} p<0.05$ vs. control (one way ANOVA followed by Dunnett's test).

\subsection{Hole Cross Test}

Table 3 represents the sedative effect of MEHL by hole cross test in mice. The number of holes crossed significantly decreased $(\mathrm{p}<0.05)$ by standard drug (diazepam, $1 \mathrm{mg} / \mathrm{kg}$ ) and MEHL (100 mg/kg, $200 \mathrm{mg} / \mathrm{kg}$ and $300 \mathrm{mg} / \mathrm{kg}$ ) successively. We also noticed that the hole cross activity significantly decreased by third $(60 \mathrm{~min})$ and continued to fifth $(120 \mathrm{~min})$ observation period of time which compared with the control group. Here, MEHL elicited sedative effect in a dose dependent manner. Results are illustrated in Figure 3.

\subsection{Pentobarbital-Induced Sleeping Time}

The results of pentobarbital-induced sleeping time in mice are demonstrated in Table 4. Here, significant decrease the onset of sleep observed by standard drug $(5.40 \pm 1.03)$ and MEHL at a dose of $300 \mathrm{mg} / \mathrm{kg}(9.60 \pm 0.93)$ body weight. In addition, significant $(\mathrm{p}<0.05)$ increase in duration of total sleeping time also observed in mice treated with MEHL at 100, 200, and $300 \mathrm{mg} / \mathrm{kg}$ as well as reference drug (diazepam, $1 \mathrm{mg} / \mathrm{kg}$ ) when compared with the control group. In this test, MEHL produced sedative effect in a dose dependent manner. Results are illustrated in Figure 4. 
Table 3. Effect of MEHL on hole cross test.

\begin{tabular}{ccccccc}
\hline Group & Dose & $0 \mathrm{~min}$ & $30 \mathrm{~min}$ & $60 \mathrm{~min}$ & $90 \mathrm{~min}$ & $120 \mathrm{~min}$ \\
\hline Control & $10 \mathrm{~mL} / \mathrm{kg}$ & $19.00 \pm 1.22$ & $19.80 \pm 1.16$ & $19.60 \pm 1.36$ & $19.40 \pm 1.47$ & $19.20 \pm 2.08$ \\
Diazepam & $1 \mathrm{mg} / \mathrm{kg}$ & $13.00 \pm 1.30$ & $10.20 \pm 0.86$ & $10.80 \pm 2.13$ & $6.40 \pm 0.93$ & $4.20 \pm 0.86$ \\
MEHL & $100 \mathrm{mg} / \mathrm{kg}$ & $16.20 \pm 2.30$ & $15.40 \pm 2.13$ & $15.00 \pm 1.58$ & $13.80 \pm 1.39$ & $12.80 \pm 1.66$ \\
MEHL & $200 \mathrm{mg} / \mathrm{kg}$ & $14.60 \pm 1.50$ & $13.00 \pm 1.30$ & $11.40 \pm 1.12$ & $9.40 \pm 0.98$ & $7.60 \pm 0.68$ \\
MEHL & $300 \mathrm{mg} / \mathrm{kg}$ & $13.00 \pm 0.84$ & $11.20 \pm 0.86$ & $9.40 \pm 0.74$ & $7.60 \pm 0.68$ & $6.40 \pm 0.51$ \\
\hline
\end{tabular}

All of the experimental values are presented as mean \pm SEM $(n=5)$, MEHL $=$ Methanol extract of Euphorbia hirta leaves. $p<0.05$ vs. control group (Dunnett's test).

\section{Hole cross test:}

Effect of MEHL and Diazepam on Hole cross test

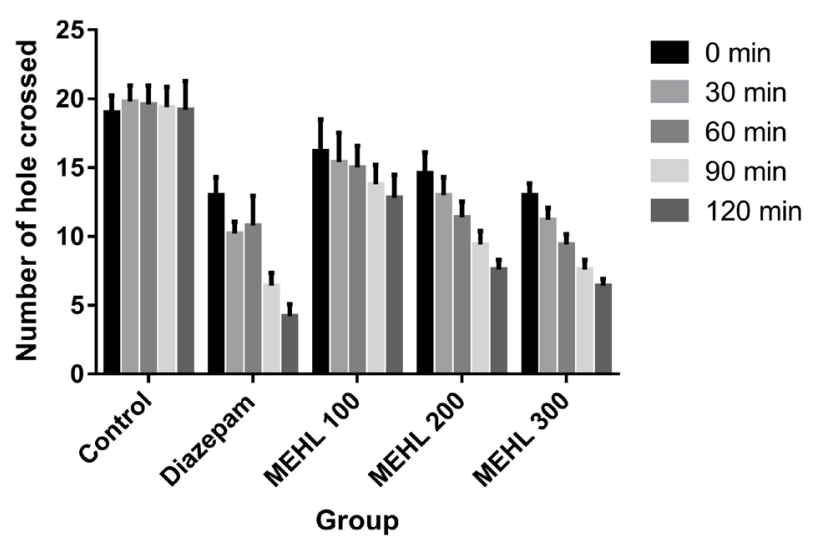

Figure 3. The effect of MEHL on the hole cross test (number of hole crossed at 0 min, 30 min, $60 \mathrm{~min}, 90 \mathrm{~min}$ and $120 \mathrm{~min}$ ) in mice. Each bar represents the mean \pm standard error of the mean of hole crosses of five animals. ${ }^{*} p<0.05$ vs. control (one way ANOVA followed by Dunnett's test).

Table 4. Effect of MEHL on pentobarbital-induced sleeping test.

\begin{tabular}{cccc}
\hline Group & Dose & Onset of sleep & Duration of sleep \\
\hline Control & $10 \mathrm{~mL} / \mathrm{kg}$ & $17.00 \pm 1.58$ & $40.60 \pm 2.93$ \\
Diazepam & $1 \mathrm{mg} / \mathrm{kg}$ & $5.40 \pm 1.03^{*}$ & $122.00 \pm 3.46^{*}$ \\
MEHL & $100 \mathrm{mg} / \mathrm{kg}$ & $14.80 \pm 2.27$ & $62.20 \pm 4.35^{\star}$ \\
MEHL & $200 \mathrm{mg} / \mathrm{kg}$ & $11.00 \pm 1.05^{\star}$ & $78.80 \pm 4.89^{\star}$ \\
MEHL & $300 \mathrm{mg} / \mathrm{kg}$ & $9.60 \pm 0.93^{*}$ & $94.40 \pm 5.83^{\star}$
\end{tabular}

All of the experimental values are presented as mean \pm SEM $(n=5)$, MEHL $=$ Methanol extract of Euphorbia hirta leaves. ${ }^{*} p<0.05$ vs. control group (Dunnett's test).

\section{Discussion}

Scientifically, medicinal plants are the affluent source of phytochemicals which are highly responsible for various biological activities and effective in treating, preventing, or improving different health conditions [20]. Several experimental investigations have been demonstrated that plant extracts contain flavonoids, glycosides, terpenoids and alkaloids possess anxiolytic and sedative properties 


\section{Sleeping time test:}

Efeect of MEHL and Diazepam on Sleeping test

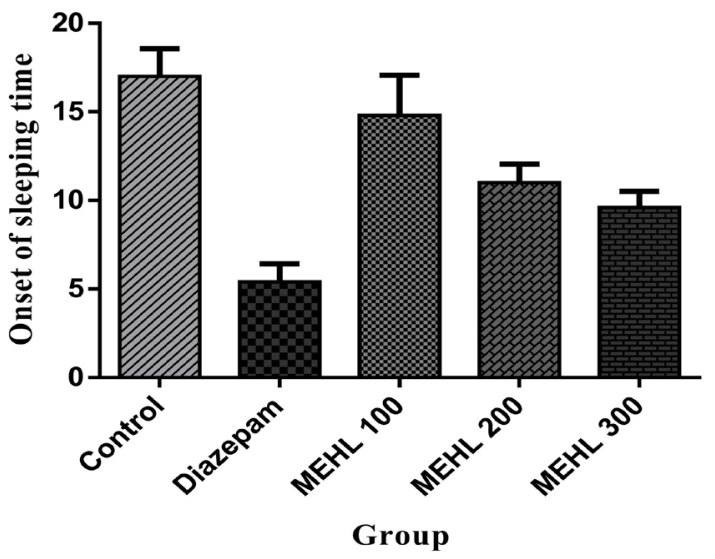

Efeect of MEHL and Diazepam on Sleeping test

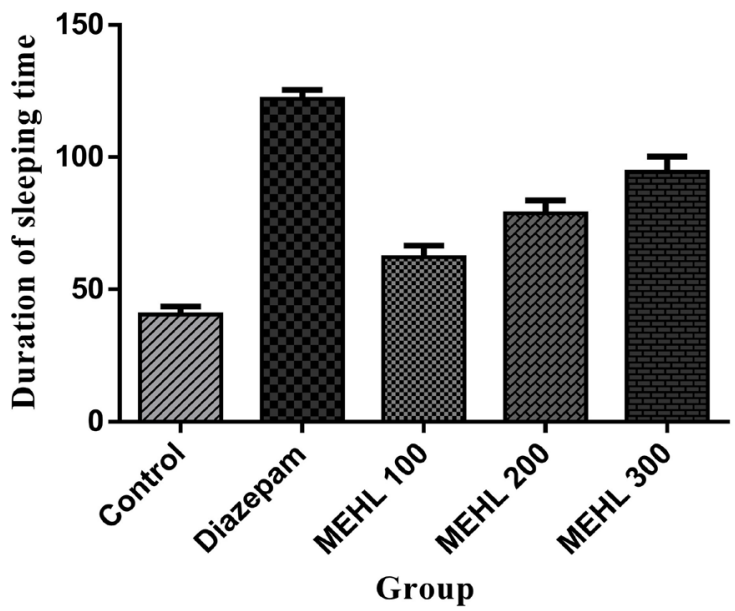

Figure 4. The effect of MEHL on the Pentobarbital-induced sleeping test (Onset and Duration of sleeping time) in mice. ${ }^{*} p<0.05$ vs. control (one way ANOVA followed by Dunnett's test).

[21] mediated through their affinity with the benzodiazepine site of the GABAergic complex system are indirect or direct modulators of this receptor. In addition, nonspecific CNS depression may also be associated with tannin [22].

To investigate the anxiolytic potential of the methanolic extract of Euphorbia hirta leaves we chose both elevated plus-maze and hole board test. Currently, the elevated plus-maze is one of the most globally preferred models of animal anxiety and has been well validated for use with both mice and rats [15]. It has been demonstrated that flavonoids are capable of fulfilling various effects on the central nervous system, emphasizing their capability to counteract psychiatric disorders in ethological models, such as the elevated plus-maze test [23]. In elevated plus maze test the anxiolytic effect of methanolic extract of Euphorbia hirta revealed by increasing the number of open arm entry and time spent into open arm of elevated plus maze compared with control group. Alternatively it decreases the number of entry and time spent into close arm compared with 
control group. Here, all dosages of MEHL exhibit significant anxiolytic effect except $100 \mathrm{mg} / \mathrm{kg}$. The dose $300 \mathrm{mg} / \mathrm{kg}$ has shown the apex anxiolytic activity than MEHL $100 \mathrm{mg} / \mathrm{kg}$ and $200 \mathrm{mg} / \mathrm{kg}$ (Table 1).

Hole board test is well-established as a means to examine effective anxiolytic and sedative properties of any agents by observing the exploratory behavior in animals. In addition, it is convenient due to its methodological simplicity and various behavioral responses of an animal can be readily observed and quantified when manifested to a new environment [24]. Our study ensured that the methanolic extract of $E$. hirta leaves produced a significant anxiolytic effect by reduction in number of head dips on hole board compared with control group. It is established that the head-dipping behavior of the animals is directly related to their emotional state and drug substances showed their anxiolytic potentiality by decreasing the number of head dips [25]. In hole board test, methanolic extract at $100 \mathrm{mg} / \mathrm{kg}$ dose did not produce a significant effect where $200 \mathrm{mg} / \mathrm{kg}$ and $300 \mathrm{mg} / \mathrm{kg}$ of plant extract willingly showed a strong anxiolytic effect by decreasing the number of head pokes. Among them, methanolic extract of $E u$ phorbia hirta at a dose of $300 \mathrm{mg} / \mathrm{kg}$ exhibits the better anxiolytic property. The reference drug diazepam also presents the profound effect in both tests in mice.

We investigated the sedative properties of the methanolic extract of Euphorbia hirta leaves through hole cross and pentobarbital-induced sleeping test in animals. The result of hole cross test showed that the MEHL decreased the frequency of movements through the hole at all dosages $(100 \mathrm{mg} / \mathrm{kg}, 200 \mathrm{mg} / \mathrm{kg}$ and $300 \mathrm{mg} / \mathrm{kg}$ ). Locomotor activity measured the level of excitability of the central nervous system. In hole cross test, any substances that cause significant decrease in the number of movements, interpreted as a reduction in inquisitiveness of the new environment are deemed as sedatives [26]. The meaningful reduction in spontaneous motor activity could be considered as the sedative effect of the plant extracts [14]. In our study, the locomotor activity lowering effect was clearly observed at $2^{\text {nd }}$ observation $\left(30 \mathrm{~min}\right.$ ) and continued up to the $5^{\text {th }}$ observation period (120 min) in mice. Here, MEHL $300 \mathrm{mg} / \mathrm{kg}$ produced highly significant effects than MEHL $100 \mathrm{mg} / \mathrm{kg}$ and $200 \mathrm{mg} / \mathrm{kg}$ (Table 3).

The methanolic extract of Euphorbia hirta leaves significantly prolonged the pentobarbital-induced sedative effect in the parameter of duration (Table 4). This response was dose-dependent in manner and it showed a tremendous augment with the increase of dose. Generally it is accepted that the sedative effects of crude extracts or drugs can be assessed by measurement of pentobarbital-induced sleeping time in laboratory animals [27]. Substances that cause significant decrease in sleep latency and prolong sleeping time are regarded as sedatives [28]. In this test MEHL $200 \& 300 \mathrm{mg} / \mathrm{kg}$ and diazepam generated strong significant results in both latency time and duration parameter, where MEHL $100 \mathrm{mg} / \mathrm{kg}$ did not showed a significant latency period but it produced a significant duration of sleep. So, the results infer that all dosages of MEHL have potential sedative effect. 
Enhancement the action of gamma-aminobutyric acid (GABAA), benzodiazepines like diazepam shows their anxiolytic and sedative performances. Structure modification of GABAA receptor may increase the receptor activity on binding site. BZDs generally bind at the alpha subunit of protein and take a cardinal role of opening events of chloride ion $\left(\mathrm{Cl}^{-}\right)$channel which accompanied with conductance and inhibition of the action potential. In addition, the anxiolytic and sedative effects of benzodiazepines may be due to the direct activation of glycine synapses in the brain. The elucidation of our tested crude extract (MEHL) mechanism of action may similar result as well to benzodiazepines like diazepam [25].

The anxiolytic and sedative properties of MEHL could be as a result of the presence of secondary metabolites (flavonoids: quercetin, quercitrin, quercitol, rutin, leucocyanidin, leucocyanidol, myricitrin, cyanidin 3,5-diglucoside, pelargonium 3,5-diglucoside; alkaloids; tannin) in the species (Euphorbia hirta), which may have synergistic effect at single or multiple target sites associated with a physiological function. Finally, the outcomes of this study ensured that the leaves of Euphorbia hirta contain compound (s) with anxiolytic and sedative properties.

\section{Conclusion}

All these findings indicate that the methanolic extract of Euphorbia hirta possesses profound anxiolytic and sedative activity. Through the facilitation of GABA transmission, dopamine antagonism and $5-\mathrm{HT} 1 \mathrm{~B} / 2 \mathrm{C}$ receptor agonistic activity, these anxiolytic and sedative properties are possibly mediated. As trustworthy, the presence of flavonoids in this species is responsible for obtained the evidence of their anxiolytic and sedative-like effects. Nevertheless, it is necessary to continuing investigation of isolating and determining the novel active constituents and structures of this extract to suggest it as a possible phytomedicine to treat neurological disorders.

\section{Acknowledgements}

The authors are thankful to the Department of Pharmacy, Jashore University of Science \& Technology, Jashore, Bangladesh for providing facilities to carry out the research work.

\section{Funding Statement}

This research work did not have any particular funding. The total cost of completing the research work was carried by authors own finance.

\section{Authors' Contribution}

S. M. Mushiur Rahman and Sohel Rana conceived and designed the experimental work. S. M. Mushiur Rahman, Sohel Rana, Md. Nahinul Islam and Md. Atikullah performed all experiments. S. M. Mushiur Rahman and Alok Kumer interpreted the results. Md. Mehedi Hassan and Tonmoy Kumar Biswas have done 
statistical analysis and drawn the graphs. S. M. Mushiur Rahman and Sohel Rana wrote the paper. All authors read and approved the final manuscript.

\section{Ethics Approval}

Authors hereby declare that "Principles of laboratory animal care" (NIH publication No. 85-23, revised 1985) were properly followed. All experiments of this study were examined and approved by ethical research committee of Jashore University of Science and Technology, Jashore-7408, Bangladesh.

\section{Conflicts of Interest}

The authors declare no conflicts of interest regarding the publication of this paper.

\section{References}

[1] Aziz, A., Raju, G.S., Das, A., Ahmed, J. and Moghal, M.M. (2014) Evaluation of in Vitro Anthelmintic Activity, Total Phenolic Content and Cytotoxic Activity of Crinum latifolium L. (Family: Amaryllidaceae). Advanced Pharmaceutical Bulletin, 4, 15.

[2] Hasan, M.M., Hossain, A., Shamim, A. and Rahman, M.M. (2017) Phytochemical and Pharmacological Evaluation of Ethanolic Extract of Lepisanthes rubiginosa L. Leaves. BMC Complementary and Alternative Medicine, 17, 496. https://doi.org/10.1186/s12906-017-2010-y

[3] Rajeh, M.A., Zuraini, Z., Sasidharan, S., Latha, L.Y. and Amutha, S. (2010) Assessment of Euphorbia hirta L. Leaf, Flower, Stem and Root Extracts for Their Antibacterial and Antifungal Activity and Brine Shrimp Lethality. Molecules, 15, 6008 6018. https://doi.org/10.3390/molecules 15096008

[4] Kumar, S., Malhotra, R. and Kumar, D. (2010) Euphorbia hirta: Its Chemistry, Traditional and Medicinal Uses, and Pharmacological Activities. Pharmacognosy Reviews, 4, 58. https://doi.org/10.4103/0973-7847.65327

[5] Sandeep, B.P., Nilofar, S.N. and Chandrakant, S.M. (2009) Review on Phytochemistry and Pharmacological Aspects of Euphorbia hirta Linn. Journal of Pharmaceutical Research and health Care, 1, 113-133. http://www.jprhc.in/index.php/ajprhc/article/download/55/53

[6] Huang, L., Chen, S. and Yang, M. (2012) Euphorbia hirta (Feiyangcao): A Review on Its Ethnopharmacology, Phytochemistry and Pharmacology. Journal of Medicinal Plants Research, 6, 5176-5185. https://doi.org/10.5897/JMPR12.206

[7] Basma, A.A., Zakaria, Z., Latha, L.Y. and Sasidharan, S. (2011) Antioxidant Activity and Phytochemical Screening of the Methanol Extracts of Euphorbia hirta L. Asian Pacific Journal of Tropical Medicine, 4, 386-390.

https://doi.org/10.1016/S1995-7645(11)60109-0

[8] Lanhers, M.C., Fleurentin, J., Dorfman, P., Mortier, F. and Pelt, J.M. (1991) Analgesic, Antipyretic and Anti-Inflammatory Properties of Euphorbia hirta. Planta Medica, 57, 225-231. https://doi.org/10.1055/s-2006-960079

[9] Rahmati, B., Kiasalari, Z., Roghani, M., Khalili, M. and Ansari, F. (2017) Antidepressant and Anxiolytic Activity of Lavandula officinalis Aerial Parts Hydroalcoholic Extract in Scopolamine-Treated Rats. Pharmaceutical Biology, 55, 958-965. https://doi.org/10.1080/13880209.2017.1285320 
[10] Mannan, A., Abir, A.B. and Rahman, R. (2015) Antidepressant-Like Effects of Methanolic Extract of Bacopa monniera in Mice. BMC Complementary and Alternative Medicine, 15, 337. https://doi.org/10.1186/s12906-015-0866-2

[11] Rahman, M.R., Sharif, M., Ali, M. and Rajib, S.S. (2019) Evaluation of the Antidepressant-Like Activity of the Methanolic Extract of the Seeds of Sesamum indicum. Clinical Phytoscience, 5, 2. https://doi.org/10.1186/s40816-018-0098-3

[12] Khatun, A., Rahman, M., Rahman, M., Hossain, H., Jahan, I.A. and Nesa, M. (2016) Antioxidant, Antinociceptive and CNS Activities of Viscum orientale and High Sensitive Quantification of Bioactive Polyphenols by UPLC. Frontiers in Pharmacology, 7, 176. https://doi.org/10.3389/fphar.2016.00176

[13] Moniruzzaman, M., Rahman, A. and Ferdous, A. (2015) Evaluation of Sedative and Hypnotic Activity of Ethanolic Extract of Scoparia dulcis Linn. Evidence-Based Complementary and Alternative Medicine, 2015, Article ID: 873954.

https://doi.org/10.1155/2015/873954

[14] Khan, I.N., Sarker, M.M. and Ajrin, M. (2014) Sedative and Anxiolytic Effects of Ethanolic Extract of Calotropis gigantea (Asclepiadaceae) Leaves. Asian Pacific Journal of Tropical Biomedicine, 4, S400-S444. https://doi.org/10.12980/APJTB.4.2014C1147

[15] Lister, R.G. (1987) The Use of a Plus-Maze to Measure Anxiety in Mouse. Psychopharmacology, 92, 180-185. https://link.springer.com/article/10.1007/BF00177912 https://doi.org/10.1007/BF00177912

[16] Öztürk, Y., Aydin, S., Beis, R., Başer, K.H. and Berberoĝlu, H. (1996) Effects of Hypericum perforatum L. and Hypericum calycinum L. Extracts on the Central Nervous System in Mice. Phytomedicine, 3, 139-146. https://doi.org/10.1016/S0944-7113(96)80027-4

[17] Bakre, A.G., Aderibigbe, A.O. and Ademowo, O.G. (2013) Studies on Neuropharmacological Profile of Ethanol Extract of Moringa oleifera Leaves in Mice. Journal of Ethnopharmacology, 149, 783-789. https://doi.org/10.1016/j.jep.2013.08.006

[18] Komada, M., Takao, K. and Miyakawa, T. (2008) Elevated plus Maze for Mice. Journal of Visualized Experiments, No. 22, 1088. https://doi.org/10.3791/1088

[19] Williamson, E.M., Okpako, D.T. and Evans, F.J. (1996) Selection, Preparation and Pharmacological Evaluation of Plant Material. John Wiley \& Sons, Hoboken. https://www.cabdirect.org/cabdirect/abstract/19970306533

[20] Mahdi, H.J., Khan, N.A., Asmawi, M.Z., Mahmud, R., Vikneswaran, A. and Murugaiyah, L. (2018) In Vivo Anti-Arthritic and Anti-Nociceptive Effects of Ethanol Extract of Moringa oleifera Leaves on Complete Freund's Adjuvant (CFA)-Induced Arthritis in Rats. Integrative Medicine Research, 7, 85-94.

https://doi.org/10.1016/j.imr.2017.11.002

[21] Hafiz, W., Zilani, M.N., Sultana, N.A., Isalm, M.M., Anisuzzman, M. and Hossain, M.G. (2019) Neuropharmacological Potential of Ceriscoides turgida (Roxb.) Leaf and Root in Mice. Clinical Phytoscience, 5, 5. https://doi.org/10.1186/s40816-019-0099-x

[22] Kahnberg, P., Lager, E., Rosenberg, C., Schougaard, J., Camet, L., Sterner, O., Nielsen, E.Ø., Nielsen, M. and Liljefors, T. (2002) Refinement and Evaluation of a Pharmacophore Model for Flavone Derivatives Binding to the Benzodiazepine Site of the GABAA Receptor. Journal of Medicinal Chemistry, 45, 4188-4201. https://doi.org/10.1021/jm020839k

[23] Noguerón-Merino, M.C., Jiménez-Ferrer, E., Román-Ramos, R., Zamilpa, A., Tortoriello, J. and Herrera-Ruiz, M. (2015) Interactions of a Standardized Flavonoid 
Fraction from Tilia americana with Serotoninergic Drugs in Elevated plus Maze. Journal of Ethnopharmacology, 164, 319-327.

https://doi.org/10.1016/j.jep.2015.01.029

[24] Takeda, H., Tsuji, M. and Matsumiya, T. (1998) Changes in Head-Dipping Behavior in the Hole-Board Test Reflect the Anxiogenic and/or Anxiolytic State in Mice. European Journal of Pharmacology, 350, 21-29. https://doi.org/10.1016/S0014-2999(98)00223-4

[25] Shahed-Al-Mahmud, M. and Lina, S.M. (2017) Evaluation of Sedative and Anxiolytic Activities of Methanol Extract of Leaves of Persicaria hydropiper in Mice. Clinical Phytoscience, 3, 20. https://doi.org/10.1186/s40816-017-0056-5 https://link.springer.com/article/10.1186/s40816-017-0056-5

[26] Prut, L. and Belzung, C. (2003) The Open Field as a Paradigm to Measure the Effects of Drugs on Anxiety-Like Behaviors: A Review. European Journal of Pharmacology, 463, 3. https://doi.org/10.1016/S0014-2999(03)01272-X

[27] Lu, M.C. (1998) Studies on the Sedative Effect of Cistanche deserticola. Journal of Ethnopharmacology, 59, 161-165. https://doi.org/10.1016/S0378-8741(97)00108-6

[28] Rabbani, M., Sajjadi, S.E. and Mohammadi, A. (2008) Evaluation of the Anxiolytic Effect of Nepeta persica Boiss. in Mice. Evidence-Based Complementary and Alternative Medicine, 5, 181-186. https://doi.org/10.1093/ecam/nem017

\author{
Abbreviations \\ BZN: Benzodiazepine \\ CNS: Central Nervous System \\ WHO: World Health Organization \\ GABA: Gamma Amino butyric Acid \\ MEHL: Methanol extract of Euphorbia hirta Leaves \\ i.p.: Intraperitoneal \\ 5-HT 1B/2C: Mixed serotonin receptor antagonist
}

